\title{
Role of Water Molecule in the Gas-Phase Formation Process of Nitrated Polycyclic Aromatic Hydrocarbons in the Atmosphere: A Computational Study
}

\author{
Qingzhu Zhang, ${ }^{*}{ }^{\dagger}$ Rui Gao, ${ }^{\dagger}$ Fei Xu, ${ }^{\dagger}$ Qin Zhou, ${ }^{\dagger}$ Guibin Jiang, ${ }^{\dagger}$ Tao Wang, ${ }^{\S}$ Jianmin Chen, ${ }^{\dagger}$ \\ Jingtian $\mathrm{Hu}^{\dagger}{ }^{\dagger}$ Wei Jiang, ${ }^{\dagger}$ and Wenxing Wang ${ }^{*}{ }^{\dagger}$ \\ ${ }^{\dagger}$ Environment Research Institute, Shandong University, Jinan 250100, China \\ ${ }^{\ddagger}$ State Key Laboratory Environmental Chemistry and Ecotoxicology, Research Center for Eco-Environmental Sciences, Chinese \\ Academy of Sciences, Beijing 100085, China \\ ${ }^{\S}$ Department of Civil and Structural Engineering, The Hong Kong Polytechnic University, Hong Kong, China
}

Supporting Information

ABSTRACT: Nitro-PAHs are globally worrisome air pollutants because their high direct-acting mutagenicity and carcinogenicity. A mechanistic understanding of their formation is of crucial importance for successful prevention of their atmospheric pollution. Here, the formation of nitroPAHs arising from the $\mathrm{OH}$-initiated and $\mathrm{NO}_{3}$-initiated atmospheric reactions of PAHs was investigated by using quantum chemical calculations. It is widely assumed that $\mathrm{OH}$ or $\mathrm{NO}_{3}$ radicals attack on the $\mathrm{C}$ atoms of the aromatic rings in the PAH molecule, followed by the addition of $\mathrm{NO}_{2}$ to the $\mathrm{OH}-\mathrm{PAH}$ or $\mathrm{NO}_{3}-\mathrm{PAH}$ adducts at the ortho position and the loss of water or nitric acid to form nitro-PAHs. However, calculations show that the direct loss of water from the $\mathrm{OH}-\mathrm{NO}_{2}-\mathrm{PAH}$ adducts via the unimolecular

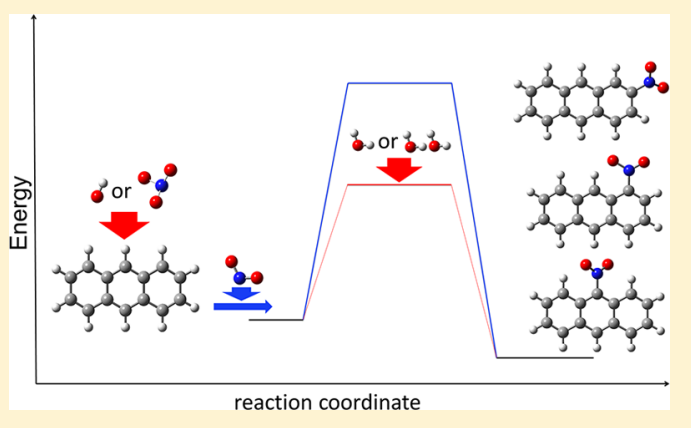
decomposition is energetically unfavorable. This study reveals for the first time that water molecule plays an important catalytic effect on the loss of water from the $\mathrm{OH}-\mathrm{NO}_{2}-\mathrm{PAH}$ adducts and promotes the formation of nitro-PAHs. In addition, the introduction of water unwraps new formation pathway through the addition of $\mathrm{NO}_{2}$ to the $\mathrm{OH}-\mathrm{PAH}$ or $\mathrm{NO}_{3}-\mathrm{PAH}$ adduct at the para position. The individual and overall rate constants for the addition reactions of PAHs with $\mathrm{OH}$ and $\mathrm{NO}_{3}$ radicals were deduced by using the Rice-Ramsperger-Kassel-Marcus (RRKM) theory.

\section{INTRODUCTION}

Atmospheric polycyclic aromatic hydrocarbons (PAHs) and their derivatives, such as nitro-PAHs, have a strong association with human lung cancer. ${ }^{1-4}$ In China, lung cancer has replaced liver cancer to become the predominant cause of cancer deaths ( $23 \%$ of cancer deaths). ${ }^{5}$ The atmospheric emission of 16 priority PAHs in all Asian countries accounted for $53.5 \%$ of the total global emissions $(504 \mathrm{Gg})$, with the highest emission from China $(106 \mathrm{Gg})$ and India $(67 \mathrm{Gg})$ in $2007 .{ }^{6}$ Consequently, the ambient air concentration of PAHs in many parts of China is orders of magnitude higher than that in developed countries. ${ }^{2}$ Although concentration of nitro-PAHs is 1-2 orders of magnitude lower than their parent PAHs, nitro-PAHs can be 100000 times more mutagenic and 10 times more carcinogenic compared to the unsubstituted-PAHs. ${ }^{7}$ Certain nitro-PAHs exhibit high direct-acting mutagenic potency in microbial mutagenicity bioassays and in forward mutation assays based on human cells. ${ }^{1}$ Nitro-PAHs have been found to account for over $50 \%$ of the total direct-acting mutagenicity and the total carcinogenicity activity of ambient air. ${ }^{8}$

Nitro-PAHs are present in the atmosphere both as a result of primary emission from incomplete combustion, primarily by diesel engines, and as a result of the secondary formation from the atmospheric reaction of PAHs. ${ }^{9}$ The specific congeners of nitro-PAHs observed in ambient air revealed that the secondary formation makes a significant contribution to the abundance profiles of nitro-PAHs. ${ }^{10-14}$ For example, the main nitro-PAH, 1nitropyrene, in diesel exhaust is generally not the predominant nitro-PAH isomer observed in ambient air. In contrast, 2nitrofluoranthene and 2-nitropyrene, which have been shown in laboratory experiments ${ }^{15,16}$ to be produced from the gas-phase reactions of PAHs, are usually more abundant nitro isomers in the atmosphere. ${ }^{10,11,17}$ In addition, nitro-PAHs have lower vapor pressures than the corresponding $\mathrm{PAHs}$ and thus promote the formation of secondary organic aerosols. ${ }^{18}$ Therefore, it is very meaningful to understand and predict the transformation of PAHs and the formation of nitro-PAHs in the atmosphere.

Nitro-PAHs can be formed in the atmosphere via homogeneous gas-phase reactions of $\mathrm{PAHs}$ with $\mathrm{OH}$ or $\mathrm{NO}_{3}$ radicals in the presence of $\mathrm{NO}_{2}$ and heterogeneous reactions of particulate PAHs with $\mathrm{N}_{2} \mathrm{O}_{5}$ or $\mathrm{HNO}_{3}$. In the atmosphere, the fraction of

Received: February 6, 2014

Revised: March 28, 2014

Accepted: April 1, 2014

Published: April 1, 2014 


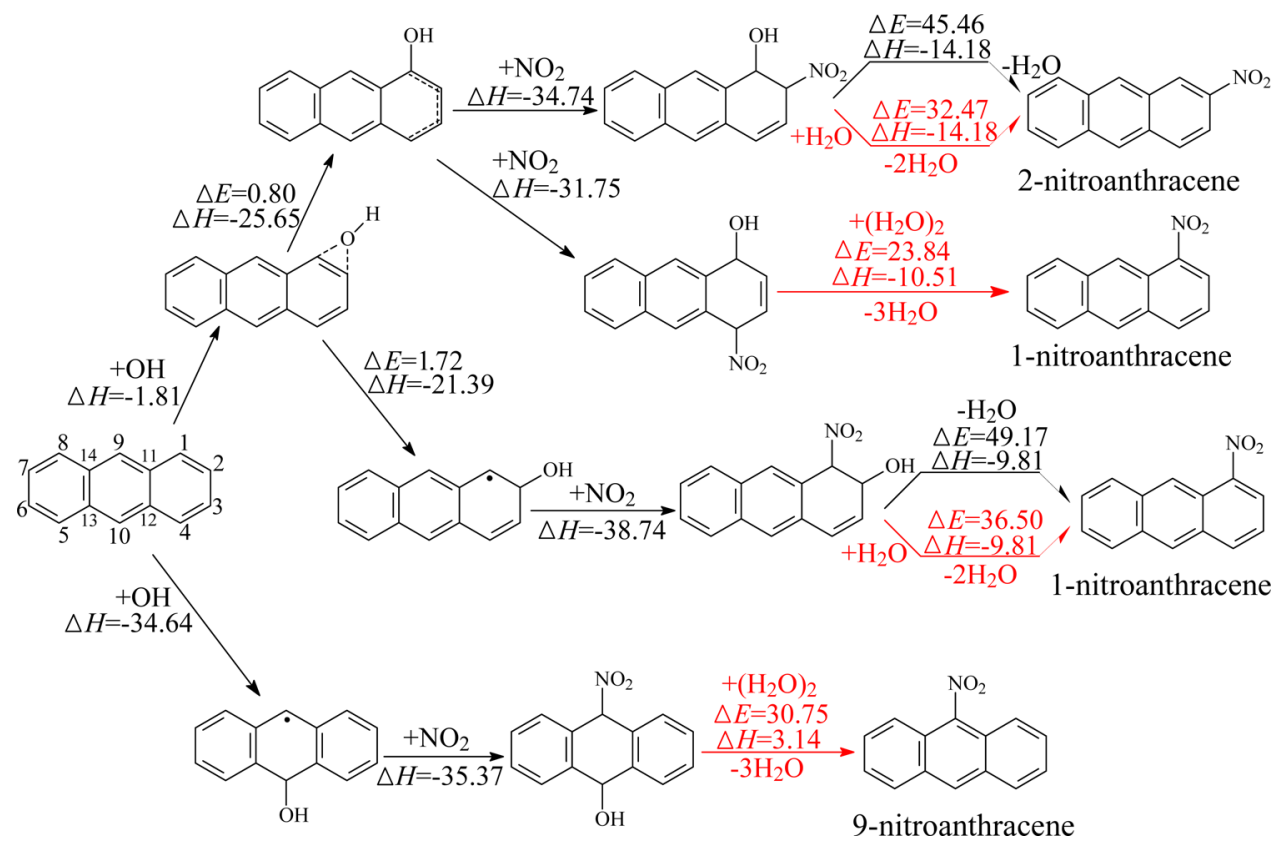

Figure 1. Nitroanthracene formation routes embedded with the potential barrier $\Delta E$ (in $\mathrm{kcal} / \mathrm{mol}$ ) and reaction heat $\Delta H$ (in $\mathrm{kcal} / \mathrm{mol}$ ) from the OHinitiated oxidation of anthracene in the presence of $\mathrm{NO}_{2} . \Delta \mathrm{H}$ is calculated at $0 \mathrm{~K}$.

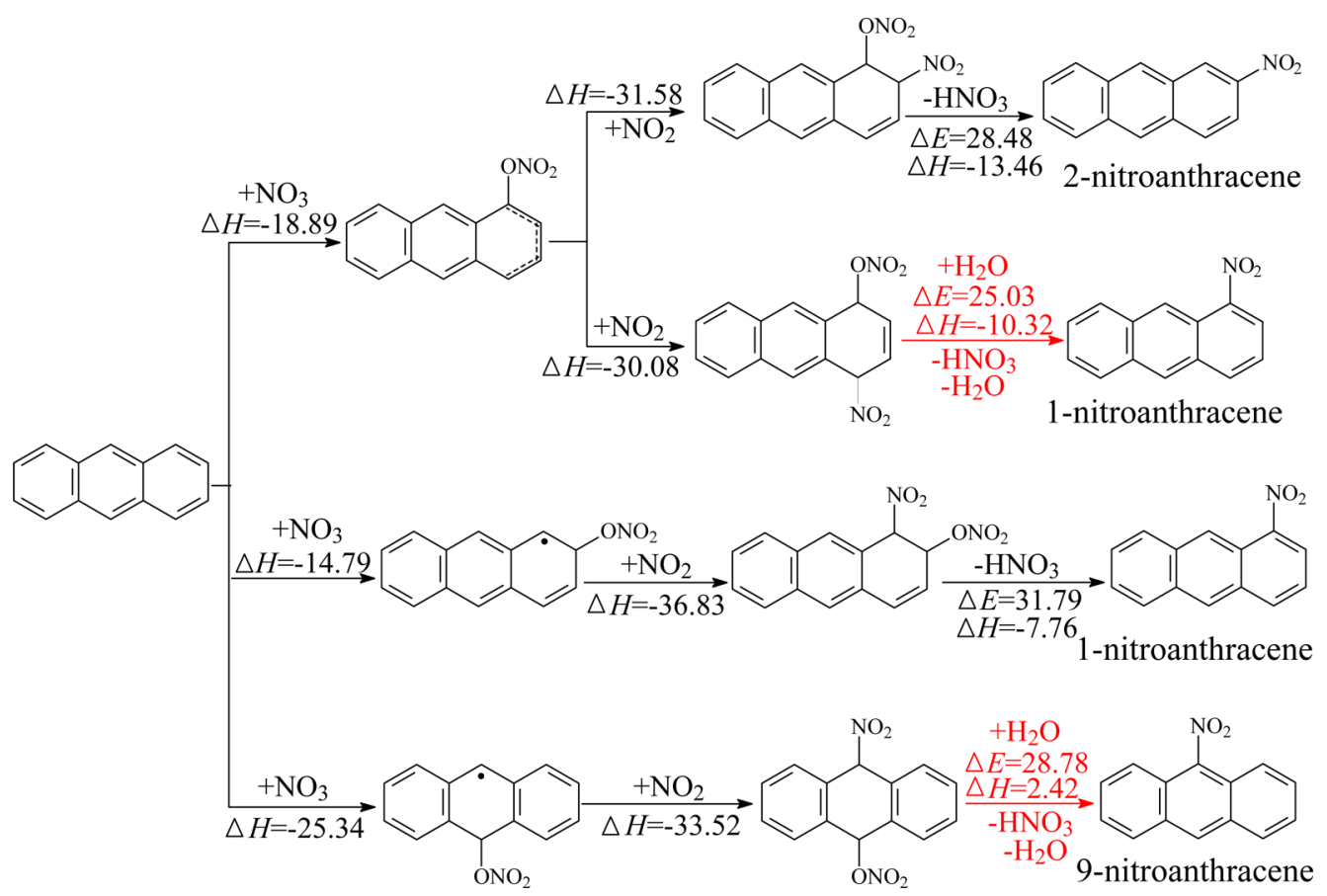

Figure 2. Nitroanthracene formation routes embedded with the potential barrier $\Delta E$ (in kcal/mol) and reaction heat $\Delta H$ (in $\mathrm{kcal} / \mathrm{mol}$ ) from the $\mathrm{NO}_{3}$ initiated oxidation of anthracene in the presence of $\mathrm{NO}_{2} . \Delta \mathrm{H}$ is calculated at $0 \mathrm{~K}$.

certain PAHs in the gaseous phase can reach up to $90 \% .{ }^{19}$ In addition, the gas-phase reactions of $\mathrm{PAHs}$ with $\mathrm{OH}$ and $\mathrm{NO}_{3}$ radicals are generally faster compared to the heterogeneous reactions of particulate PAHs with $\mathrm{N}_{2} \mathrm{O}_{5}$ or $\mathrm{HNO}_{3}{ }^{20}$ Thus, the gas-phase formation has been recognized as a significant source of nitro-PAHs in the atmosphere. It is widely assumed that $\mathrm{OH}$ or $\mathrm{NO}_{3}$ radicals attack on the $\mathrm{C}$ atoms of the aromatic rings in the $\mathrm{PAH}$ molecule, followed by the addition of $\mathrm{NO}_{2}$ to the $\mathrm{OH}-\mathrm{PAH}$ or $\mathrm{NO}_{3}-\mathrm{PAH}$ adducts at the ortho position and the loss of water or nitric acid to form nitro-PAHs. ${ }^{11}$ However, the detailed formation mechanism has still not been completely elucidated, largely due to the scarcity of efficient detection schemes for radical intermediate species and commercially available standards. $^{11,21}$ In this work, we carried out a theoretical study, employing a high-accuracy quantum chemical method. The geometrical parameters and vibrational frequencies were calculated at the BB1K level ${ }^{22}$ with the standard $6-31+G(d, p)$ basis set. Single-point energy calculations were carried out at the $\mathrm{BB} 1 K / 6-311+\mathrm{G}(3 \mathrm{df}, 2 \mathrm{p})$ level of theory. The atmospheric model places a high demand on accurate kinetic parameters. ${ }^{23}$ Therefore, the individual and overall rate constants were evaluated by using Rice-Ramsperger-Kassel-Marcus 
(RRKM) theory on the basis of the electronic structure calculations. The effect of the molecular size and steric structure of PAHs on the formation mechanism of nitro-PAHs was discussed.

\section{COMPUTATIONAL METHODS}

All the electronic structure calculations were carried out with the Gaussian 09 package on a supercomputer. ${ }^{24}$ It has been shown that the hybrid density functional theory (DFT), BB1K, can give excellent transition state geometries and barrier heights, based on Becke's 1988 gradient-corrected exchange functional (Becke88 or B) and Becke's 1995 kinetic-energy-dependent dynamical correlation functional (Becke95 or B95). ${ }^{22}$ Truhlar and coworkers pointed out that the hybrid DFT results are much less sensitive to the basis set compared to the ab initio ones, and they also emphasized the importance of diffuse functions. ${ }^{25,26}$ Therefore, the geometries of the reactants, transition states, intermediates, and products were optimized at the BB1K level with a standard $6-31+G(d, p)$ basis set. For all stationary points, frequency calculations were performed at the same level to verify whether they are minima with all positive frequencies or transition states with only one imaginary frequency. The intrinsic reaction coordinate (IRC) calculations were further carried out at the $\mathrm{BB} 1 K / 6-31+\mathrm{G}(\mathrm{d}, \mathrm{p})$ level to confirm that the transition state connects to the right minima along the reaction path. To yield more reliable energy values, a more flexible basis set, 6$311+G(3 d f, 2 p)$, was used for single-point energy calculations.

The rate constants were calculated by using the open source master equation program MESMER ${ }^{27}$ (master equation solver for multienergy well reactions) based on the Rice-RamspergerKassel-Marcus (RRKM) theory. ${ }^{28}$ The reactions related in this study occur in the atmosphere. Therefore, the default pressure value was set as $1 \mathrm{~atm}$. The RRKM rate constant is given by

$$
k(E)=\frac{W(E)}{h \rho(E)}
$$

where $W(E)$ is the rovibrational sum of states at the transition state, $\rho(E)$ is density of states of reactants, and $h$ is Planck's constant. Then, canonical rate constant $k(T)$ is determined by using the usual equation

$$
k(T)=\frac{1}{Q T} \int k(E) \rho(E) \exp (-\beta E) \mathrm{d} E
$$

where $Q(T)$ is the reactant partition function.

\section{RESULTS AND DISCUSSION}

The optimized geometries and the calculated vibrational frequencies of benzene, naphthalene, anthracene, nitrobenzene, nitronaphthalene, and 9-nitroanthracene at the BB1K/6-31+G$(\mathrm{d}, \mathrm{p})$ level are in excellent agreement with the available experimental values, and the relative deviation remains within $3.0 \%$ for the bond lengths and $8.0 \%$ for the vibrational frequencies. ${ }^{29-33}$ In order to check the reliability of the energy parameters, we calculated the reaction enthalpy for the reaction of benzene $+\mathrm{OH}+\mathrm{NO}_{2} \rightarrow$ nitrobenzene $+\mathrm{H}_{2} \mathrm{O}$. The value of $-76.50 \mathrm{kcal} / \mathrm{mol}$ deduced at the $\mathrm{BB} 1 \mathrm{~K} / 6-311+\mathrm{G}(3 \mathrm{df}, 2 \mathrm{p}) / /$ $\mathrm{BB} 1 \mathrm{~K} / 6-31+\mathrm{G}(\mathrm{d}, \mathrm{p})$ level and $298.15 \mathrm{~K}$ shows good consistency with the corresponding experimental value of $-78.28 \mathrm{kcal} / \mathrm{mol}$ obtained from the measured standard enthalpies of formation $\left(\Delta H_{\mathrm{f}}^{0}\right)$ of benzene $(19.82 \mathrm{kcal} / \mathrm{mol}), \mathrm{OH}(8.93 \mathrm{kcal} / \mathrm{mol}), \mathrm{NO}_{2}$ $(8.12 \mathrm{kcal} / \mathrm{mol})$, nitrobenzene $(16.38 \mathrm{kcal} / \mathrm{mol})$, and $\mathrm{H}_{2} \mathrm{O}$ $(-57.79 \mathrm{kcal} / \mathrm{mol}){ }^{29}$

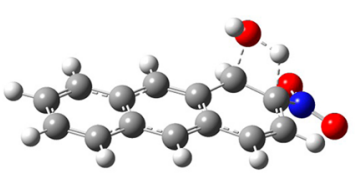

TS1

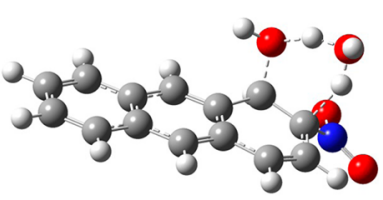

TS3

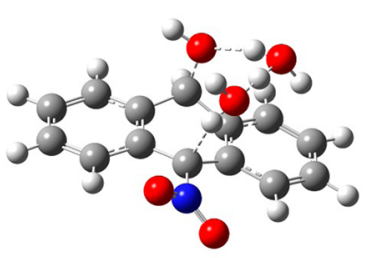

TS5

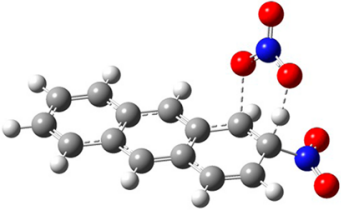

TS2

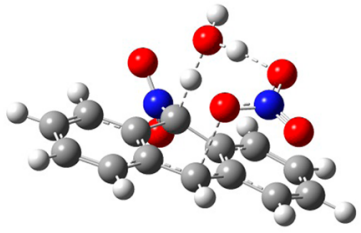

TS4
Figure 3. Configuration of the transition states for the processes of the loss of water or nitric acid. TS1: $\mathrm{OH}-\mathrm{NO}_{2}-\mathrm{PAH} \rightarrow$ nitro-PAH $+\mathrm{H}_{2} \mathrm{O}$, TS2: $\mathrm{NO}_{3}-\mathrm{NO}_{2}-\mathrm{PAH} \rightarrow$ nitro-PAH $+\mathrm{HNO}_{3}$, TS3: $\mathrm{OH}-\mathrm{NO}_{2}-\mathrm{PAH}$ $+\mathrm{H}_{2} \mathrm{O} \rightarrow$ nitro-PAH $+2 \mathrm{H}_{2} \mathrm{O}$, TS4: $\mathrm{NO}_{3}-\mathrm{NO}_{2}-\mathrm{PAH}+\mathrm{H}_{2} \mathrm{O} \rightarrow$ nitro$\mathrm{PAH}+\mathrm{HNO}_{3}+\mathrm{H}_{2} \mathrm{O}$, TS5: $\mathrm{OH}-\mathrm{NO}_{2}-\mathrm{PAH}+\left(\mathrm{H}_{2} \mathrm{O}\right)_{2} \rightarrow$ nitro-PAH + $3 \mathrm{H}_{2} \mathrm{O}$.

For convenience of description, the carbon atoms in anthracene are numbered as follows:<smiles>Cc1cccc2cc3ccccc3cc12</smiles>

The carbon atoms in other PAHs are numbered as well, as presented in the Supporting Information.

3.1. Formation Mechanism. Figures 1 and 2 (black arrows) depict the formation scheme of nitroanthracenes embedded with the potential barrier and reaction heat. The formation scheme of nitro-PAHs from the $\mathrm{OH}$ - and $\mathrm{NO}_{3}$-initiated reactions of benzene, naphthalene, fluorene, fluoranthene, phenanthrene, acenaphthene, acenaphthylene, and pyrene is presented in the Supporting Information. As the anthracene molecule at the ground state is of $D_{2 h}$ symmetry, $\mathrm{C}$ atoms in anthracene fall into four groups: $\mathrm{C} 1, \mathrm{C} 4, \mathrm{C} 5$, and $\mathrm{C} 8$ atoms belong to one equivalent group; $\mathrm{C} 2, \mathrm{C} 3, \mathrm{C} 6$, and $\mathrm{C} 7$; $\mathrm{C} 9$ and $\mathrm{C} 10$; $\mathrm{C} 11, \mathrm{C} 12, \mathrm{C} 13$, and $\mathrm{C} 14$ belong to the other equivalent groups. Therefore, four different $\mathrm{OH}-$ or $\mathrm{NO}_{3}$-anthracene adduct isomers can be formed through addition of $\mathrm{OH}$ or $\mathrm{NO}_{3}$ to $\mathrm{C} 1, \mathrm{C} 2, \mathrm{C} 9$, and $\mathrm{C} 11$ atoms, respectively. Calculations show that the addition of $\mathrm{OH}$ or $\mathrm{NO}_{3}$ to the $\mathrm{C} 9$ atom is the most exothermic and the most energetically favorable process compared with the addition of $\mathrm{OH}$ or $\mathrm{NO}_{3}$ to $\mathrm{C} 1, \mathrm{C} 2$, and $\mathrm{C} 11$ atoms. However, the reaction pathway initiated from the addition of $\mathrm{OH}$ or $\mathrm{NO}_{3}$ to the $\mathrm{C} 9$ atom cannot lead to the formation of nitroanthracene due to the lack of the ortho hydrogen. The reaction pathway through the addition of $\mathrm{OH}$ or $\mathrm{NO}_{3}$ to the $\mathrm{C} 11$ atom followed by the addition 
Table 1. Individual and Overall Rate Constants $\left(k, \mathrm{~cm}^{3}\right.$ molecule $\left.e^{-1} s^{-1}\right)$ along with Experimental Values $\left(k_{\text {expt }}\right)^{45-50}$ for the Addition Reactions of PAHs with $\mathrm{OH}$ Radicals at 298 $\mathrm{K}$ and $1 \mathrm{~atm}$

\begin{tabular}{|c|c|c|c|}
\hline PAHs & & rate constants & $k_{\text {expt }}$ \\
\hline \multirow[t]{2}{*}{ benzene } & $k$ & $1.14 \times 10^{-12}$ & $1.0 \times 10^{-12}$ \\
\hline & $k_{\mathrm{C} 1}$ & $1.91 \times 10^{-13}$ & \\
\hline \multirow[t]{3}{*}{ naphthalene } & $k$ & $1.53 \times 10^{-11}$ & $2.16 \times 10^{-11}$ \\
\hline & $k_{\mathrm{C} 1}$ & $3.34 \times 10^{-12}$ & \\
\hline & $k_{\mathrm{C} 2}$ & $4.81 \times 10^{-13}$ & \\
\hline \multirow[t]{4}{*}{ anthracene } & $k$ & $1.65 \times 10^{-10}$ & $(1.3-1.91) \times 10^{-10}$ \\
\hline & $k_{\mathrm{C} 1}$ & $1.06 \times 10^{-11}$ & \\
\hline & $k_{\mathrm{C} 2}$ & $3.85 \times 10^{-13}$ & \\
\hline & $k_{\mathrm{C} 9}$ & $6.06 \times 10^{-11}$ & \\
\hline \multirow[t]{6}{*}{ fluorene } & $k$ & $3.39 \times 10^{-12}$ & $1.3 \times 10^{-11}$ \\
\hline & $k_{\mathrm{C} 1}$ & $2.86 \times 10^{-13}$ & \\
\hline & $k_{\mathrm{C} 2}$ & $6.17 \times 10^{-13}$ & \\
\hline & $k_{\mathrm{C} 3}$ & $8.05 \times 10^{-14}$ & \\
\hline & $k_{\mathrm{C} 4}$ & $4.72 \times 10^{-13}$ & \\
\hline & $k_{\mathrm{Cla}}$ & $2.23 \times 10^{-13}$ & \\
\hline \multirow[t]{8}{*}{ fluoranthene } & $k$ & $3.84 \times 10^{-11}$ & $5 \times 10^{-11}$ \\
\hline & $k_{\mathrm{C} 1}$ & $5.37 \times 10^{-12}$ & \\
\hline & $k_{\mathrm{C} 2}$ & $2.50 \times 10^{-13}$ & \\
\hline & $k_{\mathrm{C} 3}$ & $1.28 \times 10^{-11}$ & \\
\hline & $k_{\mathrm{C} 6 \mathrm{a}}$ & $4.51 \times 10^{-16}$ & \\
\hline & $k_{\mathrm{C} 6 \mathrm{~b}}$ & $1.10 \times 10^{-15}$ & \\
\hline & $k_{\mathrm{C} 7}$ & $2.41 \times 10^{-13}$ & \\
\hline & $k_{\mathrm{C} 8}$ & $5.66 \times 10^{-13}$ & \\
\hline \multirow[t]{6}{*}{ phenanthrene } & $k$ & $3.98 \times 10^{-11}$ & $2.42 \times 10^{-11}$ \\
\hline & $k_{\mathrm{C} 1}$ & $2.43 \times 10^{-12}$ & \\
\hline & $k_{\mathrm{C} 2}$ & $1.68 \times 10^{-13}$ & \\
\hline & $k_{\mathrm{C} 3}$ & $3.84 \times 10^{-13}$ & \\
\hline & $k_{\mathrm{C} 4}$ & $7.95 \times 10^{-12}$ & \\
\hline & $k_{\mathrm{C} 10}$ & $8.97 \times 10^{-12}$ & \\
\hline \multirow[t]{5}{*}{ acenaphthene } & $k$ & $1.35 \times 10^{-10}$ & $1.0 \times 10^{-10}$ \\
\hline & $k_{\mathrm{C} 2 \mathrm{a}}$ & $2.17 \times 10^{-11}$ & \\
\hline & $k_{\mathrm{C} 3}$ & $2.06 \times 10^{-11}$ & \\
\hline & $k_{\mathrm{C} 4}$ & $8.98 \times 10^{-13}$ & \\
\hline & $k_{\mathrm{C} 5}$ & $2.45 \times 10^{-11}$ & \\
\hline \multirow[t]{6}{*}{ acenaphthylene } & $k$ & $3.64 \times 10^{-10}$ & $1.1 \times 10^{-10}$ \\
\hline & $k_{\mathrm{C} 1}$ & $1.69 \times 10^{-10}$ & \\
\hline & $k_{\mathrm{C} 2 \mathrm{a}}$ & $2.48 \times 10^{-15}$ & \\
\hline & $k_{\mathrm{C} 3}$ & $8.03 \times 10^{-13}$ & \\
\hline & $k_{\mathrm{C} 4}$ & $4.31 \times 10^{-13}$ & \\
\hline & $k_{\mathrm{C} 5}$ & $1.19 \times 10^{-11}$ & \\
\hline \multirow[t]{4}{*}{ pyrene } & $k$ & $6.58 \times 10^{-11}$ & $5 \times 10^{-11}$ \\
\hline & $k_{\mathrm{C} 1}$ & $1.11 \times 10^{-11}$ & \\
\hline & $k_{\mathrm{C} 2}$ & $2.40 \times 10^{-14}$ & \\
\hline & $k_{\mathrm{C} 4}$ & $5.35 \times 10^{-12}$ & \\
\hline
\end{tabular}

of $\mathrm{NO}_{2}$ to the $\mathrm{C} 9$ atom and the loss of water or nitric acid may yield 9-nitroanthracene. However, $\mathrm{C} 11$ is inside the "bend" of the anthracene molecule. Addition of $\mathrm{OH}$ or $\mathrm{NO}_{3}$ to the $\mathrm{C} 11$ atom is stericly hindered due to the high barrier and/or strong endothermicity. Therefore, this formation pathway of 9nitroanthracene is energetically unfavorable, and the possible nitroanthracene formation pathways may occur via addition of $\mathrm{OH}$ or $\mathrm{NO}_{3}$ to the $\mathrm{C} 1$ or $\mathrm{C} 2$ atoms.

Calculations show that the addition of $\mathrm{OH}$ or $\mathrm{NO}_{3}$ to the $\mathrm{C} 1$ and $\mathrm{C} 2$ atoms is highly exothermic with a low energy barrier or without a barrier. Addition of $\mathrm{NO}_{2}$ to the $\mathrm{OH}-$ or $\mathrm{NO}_{3}-\mathrm{PAH}$ intermediate is a barrierless and strongly exothermic process.
Table 2. Individual and Overall Rate Constants $\left(k, \mathrm{~cm}^{3}\right.$ molecule $\left.{ }^{-1} s^{-1}\right)$ along with Experimental Values $\left(k_{\text {expt }}\right)^{16,42,51-53}$ for the Addition Reactions of PAHs with $\mathrm{NO}_{3}$ Radicals at $298 \mathrm{~K}$ and $1 \mathrm{~atm}$

\begin{tabular}{|c|c|c|c|}
\hline PAHs & & rate constants & $k_{\text {expt }}$ \\
\hline \multirow[t]{2}{*}{ benzene } & $k$ & $3.66 \times 10^{-17}$ & $(2.3-5.5) \times 10^{-17}$ \\
\hline & $k_{\mathrm{C} 1}$ & $6.10 \times 10^{-18}$ & \\
\hline \multirow[t]{3}{*}{ naphthalene } & $k$ & $4.83 \times 10^{-14}$ & $9.40 \times 10^{-15}$ \\
\hline & $k_{\mathrm{C} 1}$ & $6.09 \times 10^{-15}$ & \\
\hline & $k_{\mathrm{C} 2}$ & $5.99 \times 10^{-15}$ & \\
\hline \multirow[t]{4}{*}{ anthracene } & $k$ & $5.79 \times 10^{-12}$ & $5.45 \times 10^{-12}$ \\
\hline & $k_{\mathrm{C} 1}$ & $6.00 \times 10^{-13}$ & \\
\hline & $k_{\mathrm{C} 2}$ & $5.46 \times 10^{-13}$ & \\
\hline & $k_{\mathrm{C} 9}$ & $6.04 \times 10^{-13}$ & \\
\hline \multirow[t]{6}{*}{ fluorene } & $k$ & $8.72 \times 10^{-14}$ & $3.5 \times 10^{-14}$ \\
\hline & $k_{\mathrm{C} 1}$ & $5.73 \times 10^{-15}$ & \\
\hline & $k_{\mathrm{C} 2}$ & $2.02 \times 10^{-14}$ & \\
\hline & $k_{\mathrm{C} 3}$ & $6.03 \times 10^{-15}$ & \\
\hline & $k_{\mathrm{C} 4}$ & $5.66 \times 10^{-15}$ & \\
\hline & $k_{\mathrm{Cla}}$ & $5.95 \times 10^{-15}$ & \\
\hline \multirow[t]{6}{*}{ fluoranthene } & $k$ & $5.91 \times 10^{-13}$ & \\
\hline & $k_{\mathrm{C} 1}$ & $5.98 \times 10^{-14}$ & \\
\hline & $k_{\mathrm{C} 2}$ & $5.74 \times 10^{-14}$ & \\
\hline & $k_{\mathrm{C} 3}$ & $6.25 \times 10^{-14}$ & \\
\hline & $k_{\mathrm{C} 7}$ & $5.67 \times 10^{-14}$ & \\
\hline & $k_{\mathrm{C} 8}$ & $5.90 \times 10^{-14}$ & \\
\hline \multirow[t]{6}{*}{ phenanthrene } & $k$ & $5.84 \times 10^{-13}$ & $1.2 \times 10^{-13}$ \\
\hline & $k_{\mathrm{C} 1}$ & $5.98 \times 10^{-14}$ & \\
\hline & $k_{\mathrm{C} 2}$ & $5.43 \times 10^{-14}$ & \\
\hline & $k_{\mathrm{C} 3}$ & $5.82 \times 10^{-14}$ & \\
\hline & $k_{\mathrm{C} 4}$ & $5.97 \times 10^{-14}$ & \\
\hline & $k_{\mathrm{C} 10}$ & $5.99 \times 10^{-14}$ & \\
\hline \multirow[t]{5}{*}{ acenaphthene } & $k$ & $4.80 \times 10^{-13}$ & $4.59 \times 10^{-13}$ \\
\hline & $k_{\mathrm{C} 2 \mathrm{a}}$ & $5.97 \times 10^{-14}$ & \\
\hline & $k_{\mathrm{C} 3}$ & $6.02 \times 10^{-14}$ & \\
\hline & $k_{\mathrm{C} 4}$ & $5.96 \times 10^{-14}$ & \\
\hline & $k_{\mathrm{C} 5}$ & $6.06 \times 10^{-14}$ & \\
\hline \multirow[t]{6}{*}{ acenaphthylene } & $k$ & $4.52 \times 10^{-12}$ & $5.45 \times 10^{-12}$ \\
\hline & $k_{\mathrm{C} 1}$ & $6.14 \times 10^{-13}$ & \\
\hline & $k_{\mathrm{C} 2 \mathrm{a}}$ & $2.89 \times 10^{-14}$ & \\
\hline & $k_{\mathrm{C} 3}$ & $5.99 \times 10^{-13}$ & \\
\hline & $k_{\mathrm{C} 4}$ & $4.09 \times 10^{-13}$ & \\
\hline & $k_{\mathrm{C} 5}$ & $6.10 \times 10^{-13}$ & \\
\hline \multirow[t]{4}{*}{ pyrene } & $k$ & $4.94 \times 10^{-12}$ & \\
\hline & $k_{\mathrm{C} 1}$ & $8.33 \times 10^{-14}$ & \\
\hline & $k_{\mathrm{C} 2}$ & $5.96 \times 10^{-13}$ & \\
\hline & $k_{\mathrm{C} 4}$ & $5.98 \times 10^{-13}$ & \\
\hline
\end{tabular}

The $\mathrm{OH}-\mathrm{NO}_{2}-\mathrm{PAH}$ or $\mathrm{NO}_{3}-\mathrm{NO}_{2}-\mathrm{PAH}$ adducts may subsequently undergo unimolecular decomposition to yield nitro-PAHs through the direct loss of water or nitric acid. The process of the direct loss of water or nitric acid requires crossing a high barrier. In particular, as shown in Figure 1 and the Supporting Information, the barriers of the direct loss of water via the unimolecular decomposition are extremely high. For example, the barriers of the direct loss of water from $\mathrm{OH}-$ $\mathrm{NO}_{2}$-anthracene are more than $45 \mathrm{kcal} / \mathrm{mol}$. The transition states of the direct loss of water even lie at $5.40-20.44 \mathrm{kcal} / \mathrm{mol}$ above the energy of $\mathrm{OH}-\mathrm{PAH}+\mathrm{NO}_{2}$. This inhibits the direct loss of water from proceeding beyond the formation of the adduct $\mathrm{OH}-\mathrm{NO}_{2}-\mathrm{PAH}$. As seen in Figure 3, the direct loss of water proceeds via a four-membered ring transition state, 
whereas the loss of nitric acid proceeds via a six-membered ring transition state. The bond angles in the four-membered ring are more bent than those in the six-membered ring (for example $77.0^{\circ}, 115.9^{\circ}, 71.8^{\circ}$, and $95.2^{\circ}$ in $\mathrm{TS} 1$ vs $123.7^{\circ}, 117.8^{\circ}, 106.8^{\circ}$, $168.1^{\circ}, 98.9^{\circ}$, and $104.2^{\circ}$ in TS2). The ring tension in the fourmembered ring is also larger. However, field studies showed that the $\mathrm{OH}$-initiated formation of nitro-PAHs is dominant compared with the $\mathrm{NO}_{3}$-initiated formation. For example, the contribution of the OH-initiated formation is $>90 \%$ in Denmark and $>45 \%$ during summertime and $>83 \%$ during wintertime in the midAtlantic region. ${ }^{10,34}$ The main question is how to explain the nitro-PAH formation from the $\mathrm{OH}$-initiated reactions of PAHs. There must be some other mechanism in its action.

Water is the third most abundant species in the atmosphere after $\mathrm{N}_{2}$ and $\mathrm{O}_{2}$, with a typical gas-phase concentration of $7.64 \times$ $10^{17}$ molecules $\mathrm{cm}^{-3}$, corresponding to $50 \%$ of relative humidity at $298 \mathrm{~K}$. Besides the greenhouse effect, water plays an important role in several gas-phase chemical processes occurring in the earth's atmosphere. For example, it can participate actively the gas-phase reaction of $\mathrm{SO}_{3}$ with $\mathrm{H}_{2} \mathrm{O}$ to produce $\mathrm{H}_{2} \mathrm{SO}_{4}{ }^{35}$ and the $\mathrm{H}$-abstraction from $\mathrm{HOCl}$ by $\mathrm{OH}$ radicals ${ }^{36}$ through its ability to form hydrogen bonds. An intriguing question is whether water can have an effect on the loss of water from the $\mathrm{OH}-\mathrm{NO}_{2}-\mathrm{PAH}$ adducts. To answer this question, the following quantum chemical calculations were conducted. With the introduction of water, the loss of water from the $\mathrm{OH}-\mathrm{NO}_{2}-\mathrm{PAH}$ adducts becomes a bimolecular reaction $\left(\mathrm{OH}-\mathrm{NO}_{2}-\mathrm{PAH}+\mathrm{H}_{2} \mathrm{O}\right)$. As shown in Figure 3, a six-membered ring transition state (TS3) was identified, in which water molecule acts as a bridge, accepting the hydrogen from the aromatic ring and simultaneously donating another hydrogen atom to the phenolic group. This reaction process breaks a bond in the original water molecule and leads to the formation of nitro-PAHs. Hence, the water molecule in the products is not the original one. The barriers of the loss of water via the bimolecular reaction are $9.94-14.73 \mathrm{kcal} / \mathrm{mol}$ lower compared to the direct loss of water via the unimolecular decomposition. The water molecule stabilizes the transition state and drastically lowers the reaction barrier. Thus, the water molecule plays a positive catalytic effect on the loss of water from the $\mathrm{OH}-\mathrm{NO}_{2}-\mathrm{PAH}$ adducts and promotes the formation of nitro-PAHs.

The $\mathrm{OH}-$ or $\mathrm{NO}_{3}-\mathrm{PAH}$ adduct has an unpaired electron and is a hybrid of several resonance structures, as depicted in Figure S1 of the Supporting Information. The unpaired electron can be distributed to the ortho position and the para position of the $\mathrm{OH}-$ or $\mathrm{NO}_{3}-$ group, and $\mathrm{NO}_{2}$ can be added to those positions. The pathway through the addition of $\mathrm{NO}_{2}$ to the $\mathrm{OH}-\mathrm{PAH}$ adduct at the para position followed by the direct loss of water via unimolecular decomposition is improbable due to the large distance between oxygen and hydrogen atoms to leave. This calculation shows that the pathway through the addition of $\mathrm{NO}_{2}$ to the $\mathrm{NO}_{3}-\mathrm{PAH}$ adduct at the para position followed by the direct loss of nitric acid via unimolecular decomposition is unfeasible as well due to one of the two reasons: high barrier of the loss of nitric acid and the steric hindrance from the adjacent aromatic rings. However, with the aid of a water molecule, nitroPAHs can be formed from the reaction pathway through the addition of $\mathrm{NO}_{2}$ to the $\mathrm{NO}_{3}-\mathrm{PAH}$ adduct at the para position followed by the loss of nitric acid via $\mathrm{NO}_{3}-\mathrm{NO}_{2}-\mathrm{PAH}+\mathrm{H}_{2} \mathrm{O} \rightarrow$ nitro-PAH $+\mathrm{HNO}_{3}+\mathrm{H}_{2} \mathrm{O}$. Similarly, with the introduction of two water molecules, nitro-PAHs can be formed from the pathway through the addition of $\mathrm{NO}_{2}$ to the $\mathrm{OH}-\mathrm{PAH}$ adduct at the para position followed the loss of water via $\mathrm{OH}-\mathrm{NO}_{2}-\mathrm{PAH}$
$+\mathrm{H}_{2} \mathrm{O}+\mathrm{H}_{2} \mathrm{O} \rightarrow$ nitro-PAH $+3 \mathrm{H}_{2} \mathrm{O}$. Since the simultaneous collision of three molecules $\left(\mathrm{OH}-\mathrm{NO}_{2}-\mathrm{PAH}+\mathrm{H}_{2} \mathrm{O}+\mathrm{H}_{2} \mathrm{O}\right)$ is very improbable, in this water loss reaction, the termolecular mechanism is ruled out. Hence, the most probable mechanism is the reaction of $\mathrm{OH}-\mathrm{NO}_{2}-\mathrm{PAH}$ with the water dimer, i.e., $\mathrm{OH}-$ $\mathrm{NO}_{2}-\mathrm{PAH}+\left(\mathrm{H}_{2} \mathrm{O}\right)_{2} \rightarrow$ nitro-PAH $+3 \mathrm{H}_{2} \mathrm{O}$. A field measurement by near-infrared spectroscopy has revealed a relatively high concentration of $6 \times 10^{14}$ molecules $\mathrm{cm}^{-3}$ of water dimer in the atmosphere. ${ }^{37,38}$

9-Nitroanthracene is one of the most abundant nitro-PAHs in the atmosphere. It has been suggested that 9-nitroanthracene cannot be formed from the $\mathrm{OH}$ or $\mathrm{NO}_{3}$ radical-initiated gasphase reaction of anthracene due to the reason given above, and the presence of 9-nitroanthracene in the atmosphere is from a combination of primary emissions and heterogeneous reactions. ${ }^{34,39}$ The present study drastically changes the traditional view $^{34,39}$ and reveals for the first time that 9-nitroanthracene can be formed from the $\mathrm{OH}$ or $\mathrm{NO}_{3}$ radical-initiated gas-phase reaction of anthracene through the addition of $\mathrm{OH}$ or $\mathrm{NO}_{3}$ to the $\mathrm{C} 10$ atom followed by the addition of $\mathrm{NO}_{2}$ to the $\mathrm{C} 9$ atom (para position relative to the $\mathrm{C} 10$ atom) and the loss of water or nitric acid via the bimolecular reaction with the aid of water. The formation scheme embedded with the potential barrier and reaction heat is displayed in Figures 1 and 2 (red arrows). 9Nitroanthracene was observed in a laboratory experiment, but it was ascribed to artifact formation during sampling. ${ }^{39}$

It is worth discussing the effect of the molecular size and steric structure of PAHs on the $\mathrm{OH}$ or $\mathrm{NO}_{3}$ addition reaction as well as the formation mechanism of nitro-PAHs. First, we analyze three relatively simple PAHs, benzene, naphthalene, and anthracene. The ranking of the exothermicity for the addition reaction of PAHs with $\mathrm{OH}$ or $\mathrm{NO}_{3}$ is as follows: benzene < naphthalene < anthracene. More aromatic rings increase the potential of the addition reaction. This is consistent with the experimental phenomena that the $\mathrm{OH}$ or $\mathrm{NO}_{3}$ addition rate coefficient increases strongly from benzene to naphthalene, and to anthracene. ${ }^{40-44}$ The potential barrier of the loss of water or nitric acid from the $\mathrm{OH}-\mathrm{NO}_{2}-\mathrm{PAH}$ or $\mathrm{NO}_{3}-\mathrm{NO}_{2}-\mathrm{PAH}$ adducts (with or without the aid of water) increases when the $\mathrm{PAH}$ molecule size increases from benzene to anthracene, leading to the decrease in the nitro-PAH formation potential. Phenanthrene and anthracene have the same molecular size but different steric structure. However, the addition reaction of phenanthrene with $\mathrm{OH}$ or $\mathrm{NO}_{3}$ is less exothermic than the corresponding reaction of anthracene. In addition, the loss of water or nitric acid from the $\mathrm{OH}-\mathrm{NO}_{2}-$ phenanthrene or $\mathrm{NO}_{3}-$ $\mathrm{NO}_{2}$ - phenanthrene adducts has a lower barrier compared to the $\mathrm{OH}-\mathrm{NO}_{2}$-anthracene or $\mathrm{NO}_{3}-\mathrm{NO}_{2}$-anthracene adducts. Thus, the steric structure of PAHs has an effect on the formation mechanism of nitro-PAHs as well.

3.2. Rate Constant Calculations. The formation rate and yield of nitro-PAHs depend on the ambient $\mathrm{PAH}, \mathrm{OH}$ and $\mathrm{NO}_{3}$ radical concentrations, and the rate constants for the reactions of the parent PAHs with $\mathrm{OH}$ and $\mathrm{NO}_{3}$ radicals. Several experimental studies are on record for the reaction rates of PAHs with $\mathrm{OH}$ and $\mathrm{NO}_{3}$ radicals. ${ }^{16,42,45-53}$ However, the reported values are the overall rate constants of the addition reaction. There is a notable absence of the individual rate constants. In this work, the individual and overall rate constants for the addition reactions of $\mathrm{PAHs}$ with $\mathrm{OH}$ and $\mathrm{NO}_{3}$ radicals were computed with the aid of the RRKM theory at $298 \mathrm{~K}$ and 1 atm. The RRKM method has been successfully used to deal with several reactions. ${ }^{27,54,55}$ The calculated values along with the 
available experimental data are listed in Table 1 for the addition reactions of PAHs with $\mathrm{OH}$ radicals and Table 2 for the addition reactions of PAHs with $\mathrm{NO}_{3}$ radicals. Taking anthracene as an example, the individual rate constants for the $\mathrm{OH}$ or $\mathrm{NO}_{3}$ addition to the $\mathrm{C} 1, \mathrm{C} 2$ and $\mathrm{C} 9$ atoms are noted as $k_{\mathrm{C} 1}, k_{\mathrm{C} 2}$, and $k_{\mathrm{C} 9}$, respectively. The overall rate constants of the addition reaction of anthracene $\mathrm{OH}$ or $\mathrm{NO}_{3}$ with are noted as $k, k=4 k_{\mathrm{C} 1}+$ $4 k_{\mathrm{C} 2}+2 k_{\mathrm{C} 9}$.

It is vital to clarify the reliability of the RRKM method. As is clear from Tables 1 and 2, the calculated overall rate constants for the addition reactions of benzene, naphthalene, anthracene, fluorene, fluoranthene, phenanthrene, acenaphthene, acenaphthylene, and pyrene with $\mathrm{OH}$ radicals and $\mathrm{NO}_{3}$ radicals are in excellent agreement with the experimental values, and the discrepancy remains within 4 times. For example, the RRKM rate constant, $1.65 \times 10^{-10} \mathrm{~cm}^{3}$ molecule $\mathrm{e}^{-1} \mathrm{~s}^{-1}$, agrees well with the experimental value ${ }^{51}$ of $(1.3-1.91) \times 10^{-10} \mathrm{~cm}^{3}$ molecule $^{-1} \mathrm{~s}^{-1}$ for the addition reaction of anthracene with $\mathrm{OH}$ radicals. From the good agreement with experimental values, it might be inferred that the RRKM individual rate constants are reasonable.

In summary, this study investigated theoretically the nitro$\mathrm{PAH}$ formation arising from the $\mathrm{OH}$-initiated and $\mathrm{NO}_{3}$-initiated homogeneous reactions of benzene, naphthalene, anthracene, fluorene, fluoranthene, phenanthrene, acenaphthene, acenaphthylene, and pyrene. This work shows for the first time that water plays a positive catalytic role in the loss of water from the $\mathrm{OH}-$ $\mathrm{NO}_{2}-\mathrm{PAH}$ adducts and unwraps new formation pathway through the addition of $\mathrm{NO}_{2}$ to the $\mathrm{OH}-\mathrm{PAH}$ or $\mathrm{NO}_{3}-\mathrm{PAH}$ adduct at the para position. The present study reveals for the first time that 9-nitroanthracene can be formed from the $\mathrm{OH}$ or $\mathrm{NO}_{3}$ radical-initiated gas-phase reaction of anthracene.

\section{ASSOCIATED CONTENT}

\section{S Supporting Information}

Resonance structures of the $\mathrm{OH}$-anthracene adduct; formation scheme of nitro-PAHs from the $\mathrm{OH}$ - and $\mathrm{NO}_{3}$-initiated reactions of benzene, naphthalene, fluorene, fluoranthene, phenanthrene, acenaphthene, acenaphthylene, and pyrene. This material is available free of charge via the Internet at http://pubs.acs.org.

\section{AUTHOR INFORMATION}

\section{Corresponding Authors}

*Fax: 86-531-8836 1990. E-mail: zqz@sdu.edu.cn.

*Fax: 86-531-8836 1990. E-mail: wxwang@sdu.edu.cn.

\section{Notes}

The authors declare no competing financial interest.

\section{ACKNOWLEDGMENTS}

The work was financially supported by the NSFC (National Natural Science Foundation of China, Project Nos. 21337001, 21377073, and 21177076), Taishan Grand (No. ts20120522), and Independent Innovation Foundation of Shandong University (IIFSDU, Project No. 2012JC030).

\section{REFERENCES}

(1) Finlayson-Pitts, B. J.; Pitts, J. N., Jr. Tropospheric air pollution: ozone, airborne toxics, polycyclic aromatic hydrocarbons, and particles. Science 1997, 276 (5315), 1045-1051.

(2) Zhang, Y. X.; Tao, S.; Shen, H. Z.; Ma, J. M. Inhalation exposure to ambient polycyclic aromatic hydrocarbons and lung cancer risk of Chinese population. Proc. Natl. Acad. Sci. U.S.A. 2009, 106 (50), 2106321067.
(3) Abedi-Ardekani, B.; Kamangar, F.; Hewitt, S. M.; Hainaut, P.; Sotoudeh, M.; Abnet, C. C.; Taylor, P. R.; Boffetta, P.; Malekzadeh, R; Dawsey, S. M. Polycyclic aromatic hydrocarbon exposure in oesophageal tissue and risk of oesophageal squamous cell carcinoma in north-eastern Iran. Gut 2010, 59 (9), 1178-1183.

(4) Motorykin, O.; Matzke, M. M.; Waters, K. M.; Massey Simonich, S. L. Association of carcinogenic polycyclic aromatic hydrocarbon emissions and smoking with lung cancer mortality rates on a global scale. Environ. Sci. Technol. 2013, 47 (7), 3410-3416.

(5) Wang, J.; Chen, S. J.; Tian, M.; Zheng, X. B.; Gonzales, L.; Ohura, T.; Mai, B. X.; Simonich, S. L. M. Inhalation cancer risk associated with exposure to complex polycyclic aromatic hydrocarbon mixtures in an electronic waste and urban area in south China. Environ. Sci. Technol. 2012, 46 (17), 9745-9752.

(6) Shen, H. Z.; Huang, Y.; Wang, R.; Zhu, D.; Li, W.; Shen, G. F.; Wang, B.; Zhang, Y. Y.; Chen, Y. C.; Lu, Y.; Chen, H.; Li, T. C.; Sun, K.; Li, B. G.; Liu, W. X.; Liu, J. F.; Tao, S. Global atmospheric emissions of polycyclic aromatic hydrocarbons from 1960 to 2008 and future predictions. Environ. Sci. Technol. 2013, 47 (12), 6415-6424.

(7) Durant, J. L.; Busby, W. F., Jr.; Lafleur, A. L.; Penman, B. W.; Crespi, C. L. Human cell mutagenicity of oxygenated, nitrated and unsubstituted polycyclic aromatic hydrocarbons associated with urban aerosols. Mutat. Res. 1996, 371 (3-4), 123-157.

(8) Lu, Y. M.; Ding, X. C.; Ye, S. H.; Jin, X. P. Mutagenicity of various organic fractions of diesel exhaust particles. Environ. Health. Prev. Med. 1999, 4 (1), 9-12.

(9) Ringuet, J.; Leoz-Garziandia, E.; Budzinski, H.; Villenave, E.; Albinet, A. Particle size distribution of nitrated and oxygenated polycyclic aromatic hydrocarbons (NPAHs and OPAHs) on traffic and suburban sites of a European megacity: Paris (France). Atmos. Chem. Phys. 2012, 12 (18), 8877-8887.

(10) Bamford, H. A.; Baker, J. E. Nitro-polycyclic aromatic hydrocarbon concentrations and sources in urban and suburban atmospheres of the Mid-Atlantic region. Atmos. Environ. 2003, 37 (15), 2077-2091.

(11) Reisen, F.; Arey, J. Atmospheric reactions influence seasonal PAH and nitro-PAH concentrations in the Los Angeles basin. Environ. Sci. Technol. 2004, 39 (1), 64-73.

(12) Albinet, A.; Leoz-Garziandia, E.; Budzinski, H.; Viilenave, E. Polycyclic aromatic hydrocarbons (PAHs), nitrated PAHs and oxygenated PAHs in ambient air of the Marseilles area (south of France): concentrations and sources. Sci. Total Environ. 2007, 384 (2-3), 280292.

(13) Bamford, H. A.; Bezabeh, D. W.; Schantz, M. M.; Wise, S. A.; Baker, J. E. Determination and comparison of nitrated-polycyclic aromatic hydrocarbons measured in air and diesel particulate reference materials. Chemosphere 2003, 50 (5), 575-587.

(14) Arey, J.; Zielinska, B.; Atkinson, R.; Winer, A. M. Polycyclic aromatic hydrocarbon and nitroarene concentrations in ambient air during a wintertime high-NOx episode in the Los Angeles Basin. Atmos. Environ. 1987, 21 (6), 1437-1444.

(15) Kamens, R. M.; Fan, Z.; Yao, Y.; Chen, D.; Chen, S.; Vartiainen, $\mathrm{M}$. A methodology for modeling the formation and decay of nitro-PAH in the atmosphere. Chemosphere 1994, 28 (9), 1623-1632.

(16) Fan, Z.; Chen, D.; Birla, P.; Kamens, R. M. Modeling of nitropolycyclic aromatic hydrocarbon formation and decay in the atmosphere. Atmos. Environ. 1995, 29 (10), 1171-1181.

(17) Atkinson, R.; Arey, J.; Zielinska, B.; Aschmann, S. M. Kinetics and nitro-products of the gas-phase $\mathrm{OH}$ and $\mathrm{NO}_{3}$ radical-initiated reactions of naphthalene- $d_{8}$, fluoranthene- $d_{10}$, and pyrene. Int. J. Chem. Kinetic. 1990, 22 (9), 999-1014.

(18) Lee, J. Y.; Lane, D. A. Unique products from the reaction of naphthalene with the hydroxyl radical. Atmos. Environ. 2009, 43 (32), 4886-4893.

(19) Nishino, N.; Arey, J.; Atkinson, R. Formation and reactions of 2formylcinnamaldehyde in the $\mathrm{OH}$ radical-initiated reaction of naphthalene. Environ. Sci. Technol. 2009, 43 (5), 1349-1353.

(20) Esteve, W.; Budzinski, H.; Villenave, E. Relative rate constants for the heterogeneous reactions of $\mathrm{NO}_{2}$ and $\mathrm{OH}$ radicals with polycyclic 
aromatic hydrocarbons adsorbed on carbonaceous particles. Part 2: PAHs adsorbed on diesel particulate exhaust SRM 1650a. Atmos. Environ. 2006, 40 (2), 201-211.

(21) Wang, L.; Atkinson, R.; Arey, J. Dicarbonyl products of the $\mathrm{OH}$ radical-initiated reactions of naphthalene and the $\mathrm{C} 1$ - and $\mathrm{C} 2$ alkylnaphthalenes. Environ. Sci. Technol. 2007, 41 (8), 2803-2810.

(22) Zhao, Y.; Lynch, B. J.; Truhlar, D. G. Development and assessment of a new hybrid density functional model for thermochemical kinetics. J. Phys. Chem. A 2004, 108 (14), 2715-2719.

(23) Feilberg, A.; Kamens, R. M.; Strommen, M. R.; Nielsen, T. Modeling the formation, decay, and partitioning of semivolatile nitropolycyclic aromatic hydrocarbons (nitronaphthalenes) in the atmosphere. Atmos. Environ. 1999, 33 (8), 1231-1243.

(24) Frisch, M. J.; Trucks, G. W.; Schlegel, H. B.; Scuseria, G. E.; Robb, M. A.; Cheeseman, J. R.; Scalmani, G.; Barone, V.; Mennucci, B.; Petersson, G. A.; Nakatsuji, H.; Caricato, M.; Li, X.; Hratchian, H. P.; Izmaylov, A. F.; Bloino, J.; Zheng, G.; Sonnenberg, J. L.; Hada, M.; Ehara, M.; Toyota, K.; Fukuda, R.; Hasegawa, J.; Ishida, M.; Nakajima, T.; Honda, Y.; Kitao, O.; Nakai, H.; Vreven, T.; Montgomery, J. A., Jr.; Peralta, J. E.; Ogliaro, F.; Bearpark, M.; Heyd, J. J.; Brothers, E.; Kudin, K. N.; Staroverov, V. N.; Kobayashi, R.; Normand, J.; Raghavachari, K.; Rendell, A.; Burant, J. C.; Iyengar, S. S.; Tomasi, J.; Cossi, M.; Rega, N.; Millam, J. M.; Klene, M.; Knox, J. E.; Cross, J. B.; Bakken, V.; Adamo, C.; Jaramillo, J.; Gomperts, R.; Stratmann, R. E.; Yazyev, O.; Austin, A. J.; Cammi, R.; Pomelli, C.; Ochterski, J. W.; Martin, R. L.; Morokuma, K.; Zakrzewski, V. G.; Voth, G. A.; Salvador, P.; Dannenberg, J. J.; Dapprich, S.; Daniels, A. D.; Farkas, O.; Foresman, J. B.; Ortiz, J. V.; Cioslowski, J.; Fox, D. J. Gaussian 09, revision A.02; Gaussian, Inc.: Wallingford, CT, 2009.

(25) Lynch, B. J.; Truhlar, D. G. How well can hybrid density functional methods predict transition state geometries and barrier heights? J. Phys. Chem. A 2001, 105 (13), 2936-2941.

(26) Lynch, B. J.; Zhao, Y.; Truhlar, D. G. Effectiveness of diffuse basis functions for calculating relative energies by density functional theory. $J$. Phys. Chem. A 2003, 107 (9), 1384-1388.

(27) Glowacki, D. R.; Liang, C.-H.; Morley, C.; Pilling, M. J.; Robertson, S. H. MESMER: An open-source master equation solver for multi-energy well reactions. J. Phys. Chem. A 2012, 116 (38), 95459560.

(28) Robinson, P. J.; Holbrook, K. A. Unimolecular reactions; John Wiley \& Sons: New York, 1972.

(29) Johnson III, R. D. NIST Computational Chemistry Comparison and Benchmark Database, NIST Standard Reference Database Number 101, Release 16a, Aug 2013.

(30) Cyvin, B. N.; Cyvin, S. J. Mean amplitudes of vibration of comparatively large molecules. III. Isotopic anthracene. J. Phys. Chem. 1969, 73 (5), 1430-1438.

(31) Trotter, J. Steric inhibition of resonance II. Bond lengths in mesosubstituted anthracenes. Can. J. Chem. 1959, 37 (4), 825-827.

(32) Wiberg, K. B. Properties of some condensed aromatic systems. J. Org. Chem. 1997, 62 (17), 5720-5727.

(33) Ketkar, S. N.; Fink, M. The molecular structure of naphthalene by electron diffraction. J. Mol. Struct. 1981, 77 (1-2), 139-147.

(34) Feilberg, A.; B. Poulsen, M. W.; Nielsen, T.; Henrik, S. Occurrence and sources of particulate nitro-polycyclic aromatic hydrocarbons in ambient air in Denmark. Atmos. Environ. 2001, 35 (2), 353-366.

(35) Morokuma, K.; Muguruma, C. Ab initio molecular orbital study of the mechanism of the gas phase reaction $\mathrm{SO}_{3}+\mathrm{H}_{2} \mathrm{O}$ : importance of the second water molecule. J. Am. Chem. Soc. 1994, 116 (22), 10316-10317.

(36) Gonzalez, J.; Anglada, J. M.; Buszek, R. J.; Francisco, J. S. Impact of water on the $\mathrm{OH}+\mathrm{HOCl}$ reaction. J. Am. Chem. Soc. 2011, 133 (10), $3345-3353$.

(37) Tretyakov, M. Y.; Serov, E. A.; Koshelev, M. A.; Parshin, V. V.; Krupnov, A. F. Water dimer rotationally resolved millimeter-wave spectrum observation at room temperature. Phys. Rev. Lett. 2013, 110 (9), 093001.
(38) Pfeilsticker, K.; Lotter, A.; Peters, C.; Bösch, H. Atmospheric detection of water dimers via near-infrared absorption. Science 2003, 300 (5628), 2078-2080.

(39) Arey, J.; Zielinska, B.; Atkinson, R.; Aschmann, S. M. Nitroarene products from the gas-phase reactions of volatile polycyclic aromatic hydrocarbons with the $\mathrm{OH}$ radical and $\mathrm{N}_{2} \mathrm{O}_{5}$. Int. J. Chem. Kinetic. 1989, 21 (9), 775-799.

(40) Atkinson, R; Arey, J. Atmospheric chemistry of gas-phase polycyclic aromatic hydrocarbons: formation of atmospheric mutagens. Environ. Health. Persp. 1994, 102 (Suppl 4), 117.

(41) Atkinson, R.; Arey, J. Mechanisms of the gas-phase reactions of aromatic hydrocarbons and $\mathrm{PAHs}$ with $\mathrm{OH}$ and $\mathrm{NO}_{3}$ radicals. Polycyclic Aromat. Compd. 2007, 27 (1), 15-40.

(42) Atkinson, R. Kinetics and Mechanisms of the gas-phase reactions of the $\mathrm{NO}_{3}$ radical with organic compounds. J. Phys. Chem. Ref. Data 1991, 20 (3), 459-507.

(43) Brubaker, W. W., Jr.; Hites, R. A. OH reaction kinetics of polycyclic aromatic hydrocarbons and polychlorinated dibenzo- $p$ dioxins and dibenzofurans. J. Phys. Chem. A 1998, 102 (6), 915-921.

(44) Berndt, T.; Boge, O. Gas-phase reaction of $\mathrm{OH}$ radicals with benzene: products and mechanism. Phys. Chem. Chem. Phys. 2001, 3 (22), 4946-4956.

(45) Sasaki, J.; Aschmann, S. M.; Kwok, E. S. C.; Atkinson, R.; Arey, J. Products of the gas-phase $\mathrm{OH}$ and $\mathrm{NO}_{3}$ radical-initiated reactions of naphthalene. Environ. Sci. Technol. 1997, 31 (11), 3173-3179.

(46) Lee, W.; Stevens, P. S.; Hites, R. A. Rate constants for the gasphase reactions of methylphenanthrenes with $\mathrm{OH}$ as a function of temperature. J. Phys. Chem. A 2003, 107 (34), 6603-6608.

(47) Zhou, S.; Wenger, J. C. Kinetics and products of the gas-phase reactions of acenaphthene with hydroxyl radicals, nitrate radicals and ozone. Atmos. Environ. 2013, 72, 97-104.

(48) Atkinson, R. Kinetics and mechanisms of the gas-phase reactions of the hydroxyl radical with organic compounds under atmospheric conditions. Chem. Rev. 1986, 86 (1), 69-201.

(49) Shannon, R. J.; Blitz, M. A.; Goddard, A.; Heard, D. E. Accelerated chemistry in the reaction between the hydroxyl radical and methanol at interstellar temperatures facilitated by tunnelling. Nat. Chem. 2013, 5 (9), 745-749.

(50) Glowacki, D. R.; Pilling, M. J. Unimolecular reactions of peroxy radicals in atmospheric chemistry and combustion. ChemPhysChem 2010, 11 (18), 3836-3843.

(51) Calvert, J. G.; Atkinson, R.; Becker, K. H.; Kamens, R. M.; Seinfeld, J. H.; Wallington, T. J.; Yarwood, G. The Mechanisms of Atmospheric Oxidation of Aromatic Hydrocarbons; Oxford University Press: New York, 2002.

(52) Atkinson, R.; Aschmann, S. M.; Pitts, J. N. Kinetics of the reactions of naphthalene and biphenyl with hydroxyl radicals and with ozone at $294 \pm 1 \mathrm{~K}$. Environ. Sci. Technol. 1984, 18 (2), 110-113.

(53) Atkinson, R.; Aschmann, S. M.; Pitts, J. N. J. Rate constants for the gas-phase reactions of the $\mathrm{NO}_{3}$ radical with a series of organic compounds at $296 \pm 2$ K. J. Phys. Chem. 1988, 92 (12), 3454-3457.

(54) Kwok, E. S. C.; Atkinson, R.; Arey, J. Kinetics of the gas-phase reactions of indan, indene, fluorene, and 9,10-dihydroanthracene with $\mathrm{OH}$ radicals, $\mathrm{NO}_{3}$ radicals, and $\mathrm{O}_{3}$. Int. J. Chem. Kinet. 1997, 29 (4), 299-309.

(55) Kwok, E. S. C.; Harger, W. P.; Arey, J.; Atkinson, R. Reactions of gas-phase phenanthrene under simulated atmospheric conditions. Environ. Sci. Technol. 1994, 28 (3), 521-527. 